\title{
PENGARUH PEMBERIAN VITAMIN C TERHADAP KADAR TRIGLISERIDA LANJUT USIA SETELAH PEMBERIAN JUS LIDAH BUAYA ( Aloe barbadensis Miller)
}

\author{
Farinta Annisa M, Aryu Candra Kusumastuti*)
}

Program Studi Ilmu Gizi Fakultas Kedokteran Universitas Diponegoro

J1.Dr.Sutomo No.18, Semarang, Telp (024) 8453708, Email : gizifk@ undip.ac.id

\begin{abstract}
Background : Hipertriglyceridemia is a risk factors associated with cardiovascular disease. Nutrients contained in aloe vera which predict can decrease triglyceride levels. Vitamin $C$ as an antioxidant can maintain a decrease in triglyceride levels. This study aims to determine effect vitamin $C$ on triglyceride levels after administration of aloe vera juice.

Methods : This was quasi experimental study with pre test-post test design. Subject were elderly 60-75 years old who lived in Social Rehabilitation Unit "Pucang Gading". Subject were 20 elderly with triglyceride level $\geq 100$ $\mathrm{mg} / \mathrm{dl}$, classified into 2 groups, treatment and control groups. All subjects were given aloe vera juice $200 \mathrm{ml} / \mathrm{day}$ for 14 days, then the treatment group was given vitamin $C 750 \mathrm{mg} /$ day for 3 days and control group was given placebo.Triglyceride levels was measured with GPO-PAP, Shapiro Wilk was use to analyze normaly of the data. The statistical analyzes include paired t-test and Wilcoxon.

Result : Administration aloe vera juice on treatment and control group is significantly $(p<0,05)$ decreasing triglyceride levels. There was no effect vitamin $C$ on triglyceride levels after administration aloe vera juice. There was no significant of decreasing triglyceride levels in treatment group after supplementation vitamin $C 750 \mathrm{mg}$ $(p=0,156)$. There was no diferrence of triglyceride levels $(p=0,268)$ between treatment and control groups after administration vitamin $C$.

Conclusion : Administration of vitamin C had no effect on triglyceride levels after administration aloe vera juice. Keyword : triglyceride; aloe vera juice; vitamin $C$; elderly
\end{abstract}

\begin{abstract}
ABSTRAK
Latar belakang : Hipertrigliseridemia merupakan salah satu faktor risiko terjadinya penyakit kardiovaskuler. Zat gizi yang terkandung dalam lidah buaya diduga dapat menurunkan kadar trigliserida. Vitamin C sebagai antioksidan diketahui dapat mempertahankan penurunan kadar trigliserida. Penelitian ini bertujuan untuk mengetahui pengaruh vitamin $C$ terhadap kadar trigliserida setelah pemberian jus lidah buaya.

Metode : Jenis penelitian ini adalah quasi experimental dengan rancangan pre test-post test design. Subjek adalah lansia usia 60-75 tahun yang tinggal di Unit Rehabilitasi Sosial "Pucang Gading”. Subjek adalah 20 lansia pria dan wanita dengan kadar trigliserida $\geq 100 \mathrm{mg} / \mathrm{dl}$, yang dibagi menjadi kelompok perlakuan dan kontrol. Semua subjek diberikan jus lidah buaya 200ml/ hari selama 14 hari, selanjutnya pada kelompok perlakuan diberikan vitamin C $750 \mathrm{mg} /$ hari selama 3 hari. Kadar trigliserida dianalisis dengan metode GPO-PAP. Uji normalitas menggunakan Shapiro Wilk. Analisis statistik menggunakan uji paired t-test dan Wilcoxon.

Hasil : Pemberian jus lidah buaya $200 \mathrm{ml}$ selama 14 hari pada kelompok kontrol dan perlakuan dapat menurunkan kadar trigliserida. Pemberian vitamin C $750 \mathrm{mg}$ /hari tidak berpengaruh terhadap penurunan kadar trigliserida lansia setelah pemberian jus lidah buaya $(p=0,156)$. Tidak terdapat perbedaan kadar trigliserida antara kelompok perlakuan dan kontrol setelah pemberian vitamin $C(p=0,268)$.
\end{abstract}

Simpulan : pemberian vitamin $C$ tidak berpengaruh terhadap penurunan kadar trigliserida lansia setelah pemberian jus lidah buaya.

Kata kunci : trigliserida; jus lidah buaya; vitamin C; lansia

\section{PENDAHULUAN}

Trigliserida merupakan simpanan lipid utama dalam jaringan adiposa. Lebih dari 95\% lemak yang terkandung dalam makanan tersedia dalam bentuk trigliserida. ${ }^{1}$ Kadar trigliserida yang tinggi (hipertrigliseridemia) dapat menyebabkan pembentukan plak pada dinding pembuluh darah, meningkatkan kadar Low Density Lipoprotein (LDL) dan menurunkan kadar High Density lipoprotein (HDL) sehingga meningkatkan risiko terjadinya penyakit arteri koroner. ${ }^{2}$
Menurut RISKESDAS 2013 di Indonesia prevalensi penyakit jantung sebesar 1,5\%, sementara di Jawa Tengah sebesar 1,4\%. ${ }^{3}$ Berdasarkan Laporan Kematian Akibat Penyakit Tidak Menular di kota Semarang menunjukkan sebesar 60,8\% kematian pada tahun 2011 disebabkan karena penyakit jantung dan pembuluh darah. $^{5}$

Penurunan kadar trigliserida dapat menekan risiko terjadinya penyakit kardiovaskuler. Modifikasi diet merupakan cara alternatif untuk

\footnotetext{
*)Penulis Penanggungjawab
} 
menurunkan kadar profil lipid. ${ }^{5}$ Lidah buaya (Aloe barbadensis Miller) merupakan satu bahan makanan yang dapat mempengaruhi kadar profil lipid. ${ }^{6}$ Lidah buaya memiliki banyak manfaat sebagai obat tradisional, penyubur rambut, dan juga dapat diolah menjadi berbagai macam produk seperti jus, nata de aloe, dodol, manisan dan keripik lidah buaya. Kandungan lidah buaya yang diduga dapat menurunkan kadar trigliserida adalah vitamin B3, vitamin C, Magnesium dan serat. ${ }^{7}$ Penelitian yang dilakukan pada tikus, menunjukkan bahwa air rebusan lidah buaya dapat menurunkan kadar trigliserida darah tikus dari $128,2 \pm(7,4) \mathrm{mg} / \mathrm{dl}$ menjadi $102,5 \pm(4,2) \mathrm{mg} / \mathrm{dl} .{ }^{8}$ Penelitian pada tahun 1993 menyebutkan pemberian $20 \mathrm{ml}$ lidah buaya pada 20 subyek dengan usia 40-60 tahun yang mengalami hiperkolesterolimia dan hipertrigliserida dapat menurunkan kadar kolesterol sebanyak 15,5\%, dan kadar trigliserida sebesar $31,9 \%{ }^{9}$

Penelitian dengan memberikan 1 sendok makan jus lidah buaya dua kali sehari selama 42 hari dapat menurunkan kadar trigliserida dari $220,3 \pm 11,4 \mathrm{mg} / \mathrm{dl}$ menjadi $122,7 \pm 5,5 \mathrm{mg} / \mathrm{dl} .{ }^{10}$ Studi yang dilakukan pada 15 pasien dengan usia 42-55 tahun dengan pemberian 0,05 g gel lidah buaya tiga kali sehari selama 12 minggu dapat menurunkan 35\% kadar trigliserida. ${ }^{11}$ Kandungan niasin atau vitamin B3 yang terdapat dalam lidah buaya diduga dapat mengurangi asam lemak bebas dalam darah yang mengakibatkan penurunan kadar trigliserida dan kadar LDL plasma. ${ }^{12}$

Penurunan kadar trigliserida untuk menekan risiko penyakit jantung, sebaiknya dipertahankan mencapai kadar optimal yang disarankan. Penelitian klinis menunjukkan vitamin C berperan sebagai homeostatis dengan menurunkan kadar trigliserida yang tinggi, tetapi tidak menurunkan kadar trigliserida dalam kategori normal. ${ }^{13}$ Vitamin $\mathrm{C}$ merupakan antioksidan yang dapat menurunkan kadar trigliserida dengan berperan pada reaksi hidroksilasi pembentukan asam empedu, menyebabkan peningkatan ekskresi kolesterol. Penelitian mengenai efek konsumsi vitamin $\mathrm{C}$ terhadap kadar kolesterol dan trigliserida menyebutkan setelah pemberian $2 \mathrm{~g}$ sehari vitamin $\mathrm{C}$ setelah tiga bulan akan menurunkan kadar kolesterol sebesar $38,49 \mathrm{mg} / \mathrm{dl}$ dan trigliserida $28,85 \mathrm{mg} / \mathrm{dl} .{ }^{14}$ Penelitian pada tikus menyebutkan pemberian vitamin $\mathrm{C}$ selama tiga hari dengan dosis $3,38 \mathrm{mg}$ dapat menurunkan $6,7 \mathrm{mg} / \mathrm{dl}$ kolesterol total dan pemberian vitamin $\mathrm{C}$ dengan dosis 11,25 mg menurunkan kadar kolesterol total sebesar $19,76 \mathrm{mg} / \mathrm{dl} .{ }^{15}$ Penelitian yang dilakukan pada pasien diabetes mellitus tipe 2 , pemberian vitamin
C sebanyak 266,7 $\mathrm{mg}$ selama tiga bulan dapat menurunkan kadar trigliserida dari 229,34 \pm 68 $\mathrm{mg} / \mathrm{dl}$ menjadi $166,86 \pm 51,73 \mathrm{mg} / \mathrm{dl} .{ }^{16}$ Penelitian ini bertujuan untuk mengetahui pengaruh vitamin $\mathrm{C}$ terhadap kadar trigliserida lansia setelah pemberian jus lidah buaya.

\section{METODE}

Penelitian ini merupakan penelitian quasi experimental dengan rancangan pre test- post test design yang melibatkan lansia usia 60-75 tahun yang tinggal di Unit Rehabilitasi Sosial Pucang Gading Provinsi Jawa Tengah sebagai subjek. Penelitian dilakukan selama tiga minggu pada bulan Juni 2014.

Sebanyak 33 orang bersedia diambil darahnya untuk proses skrinning, 23 orang memenuhi kriteria inklusi yaitu mempunyai kadar trigliserida $\geq 100 \mathrm{mg} / \mathrm{dl}$, dapat diajak komunikasi, tidak dalam kondisi sakit atau dalam perawatan dokter berkaitan dengan penyakit jantung koroner, diabetes melitus, dan penyakit kronis lainnya, tidak sedang mengkonsumsi obat hipertensi serta bersedia menjadi subyek penelitian dengan mengisi informed consent. Pengambilan sampel pada kelompok perlakuan dipilih 10 orang dengan cara randomize control trial sampling 10 pada kelompok kontrol dipilih secara matching variabel dengan menyamakan variabel usia dan jenis kelamin

Sebelum diberikan intervensi vitamin C, kelompok perlakuan dan kontrol diberi jus lidah buaya $200 \mathrm{ml} /$ hari selama 14 hari untuk melihat penurunan kadar trigliserida subjek. Setelah pemberian jus lidah buaya, kelompok perlakuan diberikan intervensi berupa suplementasi vitamin $\mathrm{C}$ dalam bentuk tablet hisap $750 \mathrm{mg} /$ hari selama 3 hari dan kelompok kontrol diberikan plasebo selama 3 hari, plasebo diberikan dalam bentuk permen rendah kalori. Jus lidah buaya yang diberikan pada subjek dibuat dari 120 gram daging lidah buaya yang sebelumnya telah dicuci untuk mengurangi lendir dan direbus selama 5 menit, kemudian dihaluskan dengan blender dan ditambahkan air $100 \mathrm{ml}$ serta gula rendah kalori 42 gram.

Pemberian minuman jus lidah buaya dan vitamin $\mathrm{C}$ dilakukan secara langsung oleh peneliti di panti. Selama penelitian, peneliti juga mencatat dan memantau efek samping pemberian jus lidah buaya dan vitamin $\mathrm{C}$ yang dirasakan oleh subjek. Berdasarkan hasil wawancara dan pantuan, selama mengkonsumsi jus lidah buaya dan vitamin $\mathrm{C}$ tidak terdapat efek samping yang dimuncul dan dirasakan subjek. Semua subjek pada kedua 
kelompok mampu menyelesaikan intervensi sampai akhir penelitian, sehingga tidak terdapat subjek yang dropout. Pemberian jus lidah buaya dan vitamin $\mathrm{C}$ dilakukan diantara makan pagi dan makan siang. Selama pelaksanaan penelitian peneliti menggali asupan masing-masing subyek dengan menggunakan metode food recall 24 jam yaitu, $2 \mathrm{x}$ sebelum pemberian jus lidah buaya, $5 \mathrm{x}$ selama pemberian jus lidah buaya dan $2 \mathrm{x}$ selama pemberian vitamin C. Kadar trigliserida darah dicek sebanyak $3 x$ yaitu 2 hari sebelum intervensi, setelah pemberian jus lidah buaya pada hari ke-15 dan setelah intervensi pada hari ke-18.

Data yang dikumpulkan berupa identitas dan riwayat penyakit melalui wawancara, pengukuran berat badan dan tinggi badan subyek dengan alat timbangan digital dan mikrotoa untuk mengetahui status gizi subjek berdasarkan WHO (2000) kriteria Asia Pasifik (underweight: <18,5 $\mathrm{kg} / \mathrm{m}^{2}$; normal: $18,5-22,9 \mathrm{~kg} / \mathrm{m}^{2}$; overweight: 23 $24,9 \mathrm{~kg} / \mathrm{m}^{2}$; dan obesitas: $>25 \mathrm{~kg} / \mathrm{m}^{2}$ ). Data asupan makan subyek juga didapat melalui wawancara dengan metode food recall 24 jam. Pemeriksaan kadar trigliserida dianalisis dengan menggunakan metode GPO-PAP. Sampel darah diambil oleh petugas laboratorium "I" setelah subjek berpuasa selama \pm 10 jam.

Variabel bebas dalam penelitian ini adalah pemberian jus lidah buaya $200 \mathrm{ml} / \mathrm{hari}$ selama 14 hari dan vitamin C $750 \mathrm{mg} /$ hari selama 3 hari. Variabel terikat adalah kadar trigliserida darah, variabel perancunya adalah asupan meliputi rata-rata asupan energi, protein, lemak, serat dan kolesterol. Data asupan yang diperoleh dalam ukuran rumah tangga dikonversikan kedalam satuan gram kemudian dihitung nilai energi, protein, lemak, karbohidrat, serat dan kolesterol dengan menggunakan nutrisurvey.

Semua data yang diperoleh terlebih dahulu dilakukan uji normalitas untuk menguji kenormalan data dengan uji Saphiro wilks. Perbedaan rerata asupan dan kadar trigliserida sebelum dan sesudah intervensi pada tiap kelompok serta antara kelompok perlakuan dan kontrol diuji dengan paired t-test dan Wilcoxon, hal ini dikarenakan sampel dikedua kelompok dilakukan matching sehingga sampel antara dua kelompok perlakuan dan kontrol saling berpasangan.

\section{HASIL PENELITIAN \\ Karakteristik Subyek Penelitian}

Penelitian dilakukan pada bulan April sampai Juli 2014. Karakteristik subyek meliputi usia, jenis kelamin, status gizi dan kadar trigliserida sebelum intervensi. Data usia dan jenis kelamin sudah dilakukan matching, sehingga tidak terdapat perbedaan usia antara kedua kelompok. Rerata kadar trigliserida awal sebelum diberikan jus lidah buaya pada kelompok perlakuan adalah $187,00 \mathrm{mg} / \mathrm{dl}$ dan $158,40 \mathrm{mg} / \mathrm{dl}$ pada kelompok kontrol. Tabel 1 menunjukkan tidak terdapat perbedaan status gizi antara kelompok perlakuan dan kontrol. Status gizi pada kelompok perlakuan sebagian besar tergolong obesitas (40\%).

Tabel 1. Karakteristik subjek

\begin{tabular}{|c|c|c|c|c|c|c|c|c|c|}
\hline \multicolumn{10}{|c|}{ Tadel I. naraktertstik suDjek } \\
\hline \multirow{3}{*}{ Variabel } & \multicolumn{6}{|c|}{ Kelompok } & \multirow[b]{3}{*}{$\mathbf{N}$} & \multirow[b]{3}{*}{$\%$} & \multirow{3}{*}{$\mathbf{P}$} \\
\hline & \multicolumn{2}{|c|}{$\begin{array}{c}\text { Perlakuan I } \\
(n=10)\end{array}$} & \multicolumn{4}{|c|}{$\begin{array}{c}\text { kontrol } \\
(\mathrm{n}=10)\end{array}$} & & & \\
\hline & Min & Max & $\mathbf{N}$ & $\%$ & Min & Max & & & \\
\hline \multicolumn{10}{|l|}{ Status gizi } \\
\hline $\begin{array}{l}\text { Underweight } \\
\left(<18,5 \mathrm{~kg} / \mathrm{m}^{2}\right)\end{array}$ & & & 3 & 30 & & & 4 & 40 & \\
\hline $\begin{array}{l}\text { Normal } \\
\left(18,5-22,9 \mathrm{~kg} / \mathrm{m}^{2}\right)\end{array}$ & & & 1 & 10 & & & 4 & 40 & \\
\hline $\begin{array}{l}\text { Overweight } \\
\left(23-24,9 \mathrm{~kg} / \mathrm{m}^{2}\right)\end{array}$ & 15,8 & 32,3 & 2 & 20 & 16,9 & 27,8 & 1 & 10 & $0,190^{\mathrm{b}}$ \\
\hline $\begin{array}{l}\text { Obesitas } \\
\left(>25 \mathrm{~kg} / \mathrm{m}^{2}\right)\end{array}$ & & & 4 & 40 & & & 1 & 10 & \\
\hline TOTAL & & & 10 & 100 & & & 10 & 100 & \\
\hline
\end{tabular}


Rerata asupan energi, protein, lemak, karbohidrat, kolesterol, serat dan vitamin C kelompok perlakuan dan kontrol sebelum intervensi, selama pemberian jus lidah buaya dan selama intervensi vitamin $\mathbf{C}$

Tabel 2. Rerata asupan sebelum intervensi dan selama intervensi vitamin C

\begin{tabular}{|c|c|c|c|c|c|}
\hline \multirow[t]{2}{*}{$\begin{array}{l}\text { Asupan } \\
\text { Makan }\end{array}$} & \multirow{2}{*}{$\begin{array}{c}\begin{array}{c}\text { Perlakuan } \\
(\mathbf{n}=10)\end{array} \\
\text { Mean } \pm \text { SD }\end{array}$} & \multicolumn{3}{|c|}{$\begin{array}{c}\text { Kontrol } \\
(n=10)\end{array}$} & \multirow[t]{2}{*}{$\mathbf{p}$} \\
\hline & & $\%$ & Mean \pm SD & $\%$ & \\
\hline \multicolumn{6}{|l|}{ Energi } \\
\hline Awal & $1362,55 \pm 202,31$ & & $1302,65 \pm 266,62$ & & $0,203^{\mathrm{a}}$ \\
\hline Selama pemberian jus & $1395,47 \pm 167,94$ & & $1330,74 \pm 241,27$ & & $0,074^{\mathrm{a}}$ \\
\hline Selama intervensi & $1370,03 \pm 188,80$ & & $1310,98 \pm 247,67$ & & $0,139^{\mathrm{a}}$ \\
\hline$\Delta 1$ & $32,92 \pm 42,75$ & 2,42 & $28,09 \pm 84,61$ & 2,15 & $0,859^{b}$ \\
\hline$\Delta 2$ & $-25,44 \pm 54,05$ & $-1,82$ & $-19,76 \pm 81,93$ & $-1,48$ & $0,849^{b}$ \\
\hline p1 & $0,038^{\mathrm{b} *}$ & & $0,333^{\mathrm{a}}$ & & \\
\hline p2 & $0,171^{\mathrm{b}}$ & & $0,333^{\mathrm{a}}$ & & \\
\hline \multicolumn{6}{|l|}{ Protein } \\
\hline Awal & $48,98 \pm 2,71$ & & $44,86 \pm 7,96$ & & $0,185^{\mathrm{b}}$ \\
\hline Selama pemberian jus & $51,67 \pm 2,05$ & & $47,91 \pm 5,44$ & & $0,074^{\mathrm{b}}$ \\
\hline Selama intervensi & $42,99 \pm 7,63$ & & $43,82 \pm 6,53$ & & $0,541^{\mathrm{a}}$ \\
\hline$\Delta \mathbf{1}$ & $2,69 \pm 2,53$ & 5,49 & $3,05 \pm 4,16$ & 6,79 & $0,799^{\mathrm{a}}$ \\
\hline$\Delta 2$ & $-8,68 \pm 8,17$ & $-16,79$ & $-4,09 \pm 2,72$ & $-8,53$ & $0,127^{\mathrm{b}}$ \\
\hline p1 & $0,008^{\mathrm{b} *}$ & & $0,046^{\mathrm{b} *}$ & & \\
\hline p2 & $0,028^{\mathrm{a} *}$ & & $0,001^{\mathrm{b} *}$ & & \\
\hline \multicolumn{6}{|l|}{ Lemak } \\
\hline Awal & $42,43 \pm 5,86$ & & $40,01 \pm 8,01$ & & $0,203^{\mathrm{a}}$ \\
\hline Selama pemberian jus & $48,09 \pm 5,33$ & & $45,89 \pm 6,24$ & & $0,333^{\mathrm{a}}$ \\
\hline Selama intervensi & $43,59 \pm 2,72$ & & $41,32 \pm 3,95$ & & $0,253^{\mathrm{b}}$ \\
\hline$\Delta 1$ & $5,55 \pm 2,76$ & 13,08 & $5,88 \pm 4,25$ & 14,69 & $0,830^{\mathrm{b}}$ \\
\hline$\Delta 2$ & $-4,50 \pm 5,17$ & $-9,36$ & $-4,57 \pm 7,01$ & $-9,95$ & $0,983^{\mathrm{b}}$ \\
\hline p1 & $0,005^{\mathrm{a} *}$ & & $0,007^{a *}$ & & \\
\hline p2 & $0,012^{\mathrm{a} *}$ & & $0,070^{\mathrm{b}}$ & & \\
\hline \multicolumn{6}{|l|}{ Karbohidrat } \\
\hline Awal & $197,46 \pm 39,23$ & & $184,95 \pm 54,58$ & & $0,203^{\mathrm{a}}$ \\
\hline Selama pemberian jus & $190,77 \pm 34,17$ & & $185,76 \pm 49,30$ & & $0,333^{\mathrm{a}}$ \\
\hline Selama intervensi & $205,23 \pm 41,15$ & & $195,09 \pm 53,88$ & & $0,241^{\mathrm{a}}$ \\
\hline$\Delta 1$ & $-6,70 \pm 6,51$ & $-3,39$ & $0,82 \pm 7,33$ & 0,45 & $0,146^{\mathrm{b}}$ \\
\hline$\Delta 2$ & $14,46 \pm 11,04$ & 7,58 & $9,32 \pm 13,86$ & 5,01 & $0,285^{\mathrm{a}}$ \\
\hline p1 & $0,010^{\mathrm{b} *}$ & & $0,799^{\mathrm{a}}$ & & \\
\hline p2 & $0,063^{\mathrm{b}}$ & & $0,028^{\mathrm{a}}$ & & \\
\hline \multicolumn{6}{|l|}{ Kolesterol } \\
\hline Awal & $170,38 \pm 44,05$ & & $175,98 \pm 12,56$ & & $0,213^{\mathrm{a}}$ \\
\hline Selama pemberian jus & $217,42 \pm 48,82$ & & $232,20 \pm 42,14$ & & $0,646^{\mathrm{a}}$ \\
\hline Selama intervensi & $245,55 \pm 50,12$ & & $258,90 \pm 15,66$ & & $0,953^{\mathrm{a}}$ \\
\hline$\Delta 1$ & $47,04 \pm 32,04$ & 27,60 & $74,22 \pm 42,54$ & 42,17 & $0,139^{\mathrm{a}}$ \\
\hline$\Delta 2$ & $28,13 \pm 22,73$ & 12,93 & $26,61 \pm 29,93$ & 11,45 & $0,926^{\mathrm{b}}$ \\
\hline p1 & $0,005^{\mathrm{a} *}$ & & $0,007^{\mathrm{a} *}$ & & \\
\hline p2 & $0,013^{\mathrm{a} *}$ & & $0,012^{a *}$ & & \\
\hline \multicolumn{6}{|l|}{ Serat } \\
\hline Awal & $8,09 \pm 0,90$ & & $8,32 \pm 0,90$ & & $0,316^{\mathrm{b}}$ \\
\hline Selama pemberian jus & $7,62 \pm 0,86$ & & $8,03 \pm 0,77$ & & $0,093^{\mathrm{a}}$ \\
\hline Selama intervensi & $8,57 \pm 0,98$ & & $8,64 \pm 0,61$ & & $0,771^{\mathrm{b}}$ \\
\hline$\Delta 2$ & $-0,47 \pm-0,49$ & $-5,80$ & $-0,28 \pm 0,28$ & $-3,36$ & $0,374^{\mathrm{b}}$ \\
\hline p1 & $0,95 \pm 0,85$ & 12,46 & $0,61 \pm 0,61$ & 7,59 & $0,111^{\mathrm{b}}$ \\
\hline p2 & $0,014^{\mathrm{b} *}$ & & $0,019^{\mathrm{a}}$ & & \\
\hline & $0,007^{\mathrm{b} *}$ & & $0,021^{\mathrm{a}}$ & & \\
\hline $\begin{array}{l}\text { Vitamin C } \\
\text { Selama intervensi }\end{array}$ & $37,38 \pm 6,59$ & & $34,85 \pm 8,36$ & & $0,678^{\mathrm{a}}$ \\
\hline
\end{tabular}

Keterangan: *: beda bermakna; a: Wilcoxon; $b$ : Uji beda paired t-test;
$\Delta 1$ : perubahan asupan selama pemberian jus-awal
$\Delta 2$ : perubahan asupan intervensi - pemberian jus
p: nilai p antara kelompok perlakuan dan kontrol
p1: nilai p antara asupan awal dan selama pemberian jus
p2: nilai p antara asupan selama pemberian jus dan intervensi 
Gambaran asupan subjek didapat dari hasil recall asupan sebelum intervensi, selama pemberian jus lidah buaya dan selama intervensi yang bersumber dari makanan selain pemberian jus lidah buaya dan vitamin $\mathrm{C}$. Tabel 2 menunjukkan rerata asupan energi, protein, lemak, karbohidrat, kolesterol dan serat antara kelompok perlakuan dan kontrol sebelum intervensi tidak terdapat perbedaan.

Rerata asupan energi pada kelompok perlakuan mengalami peningkatan secara bermakna selama pemberian jus lidah buaya. Rerata asupan protein dan lemak pada kelompok perlakuan dan kontrol mengalami peningkatan yang bermakna selama pemberian jus lidah buaya, pada kelompok perlakuan rerata asupan protein dan lemak mengalami penurunan yang bermakna selama intervensi vitamin $\mathrm{C}$ berangsung. Rerata asupan kelompok perlakuan pada saat pemberian jus lidah buaya mengalami penurunan yang signifikan, pada kelompok kontrol selama intervensi terjadi peningkatan rerata asupan karbohidrat.

Rerata asupan kolesterol mengalami peningkatan secara bermakna pada kedua kelompok selama pemberian jus lidah buaya dan selama intervensi vitamin $\mathrm{C}$ berlangsung. Rerata asupan serat pada kedua kelompok mengalami penurunan secara bermakna selama pemberian jus lidah buaya dan meningkat secara signifikan selama intervensi vitamin C. Rerata asupan energi, protein, lemak, karbohidrat, kolesterol, serat dan vitamin $\mathrm{C}$ selama intervensi vitamin $\mathrm{C}$ antara kelompok perlakuan dan kelompok kontrol tidak terdapat perbedaan

\section{Daya Terima Jus Lidah Buaya dan Vitamin C}

Sebelum intervensi vitamin $\mathrm{C}$, masingmasing kelompok diberikan jus lidah buaya sebanyak $200 \mathrm{ml}$. Selama pemberian jus lidah buaya terdapat satu orang subjek yang menyisakan $15 \mathrm{ml}$ jus lidah buaya selama satu kali pemberian, rerata asupan jus lidah buaya pada kelompok perlakuan adalah 199,89 $\mathrm{ml}(99,94 \%)$. Kelompok kontrol terdapat dua orang subjek yang menyisakan jus lidah buaya sebanyak $15 \mathrm{ml}$ dan 25 ml selama satu kali pemberian, sehingga rerata asupan jus lidah buaya pada kelompok kontrol adalah 199,71 ml/hari (99,86\%). Selama intervensi vitamin $\mathrm{C}$, semua subjek menghabiskan vitamin C yang diberikan. Selama penelitian tidak ditemukan efek samping pada subjek baik selama pemberian jus lidah buaya maupun selama intervensi vitamin C.

\section{Kadar trigliserida sebelum, setelah pemberian jus lidah buaya dan setelah intervensi}

Terdapat penurunan rerata kadar trigliserida yang bermakna sebelum dan sesudah pemberian jus lidah buaya pada kedua kelompok $(\mathrm{p}<0,05)$. Tidak terdapat perbedaan kadar trigliserida setelah pemberian jus lidah buaya pada hari ke 15 antara kelompok kontrol dan perlakuan $(\mathrm{p}>0,05)$.

Hasil statistik menunjukkan, kelompok perlakuan yang diberi vitamin $\mathrm{C}$ dan pada kelompok kontrol yang diberi plasebo menunjukkan tidak ada perbedaan kadar trigliserida ditunjukkan dengan nilai $p>0,05$. Tidak terdapat perbedaan kadar trigliserida akhir setelah intervensi vitamin $\mathrm{C}$ antara kelompok perlakuan dan kelompok kontrol $(\mathrm{p}>0,05)$.

Tabel 3. Rerata kadar trigliserida sebelum, setelah pemberian jus lidah buaya dan setelah intervensi

\begin{tabular}{lccc}
\hline \multicolumn{1}{c}{ Variabel } & $\begin{array}{c}\text { Perlakuan } \\
(\mathbf{n = 1 0})\end{array}$ & $\begin{array}{c}\text { Kontrol } \\
(\mathbf{n = 1 0})\end{array}$ & p \\
\cline { 2 - 3 } & Mean \pm SD & Mean \pm SD & \\
\hline Trigliserida & & & \\
$\quad$ Awal & $187,00 \pm 47,92$ & $158,40 \pm 58,95$ & $0,241^{\mathrm{a}}$ \\
Setelah pemberian jus & $148,70 \pm 49,09$ & $127,10 \pm 21,88$ & $0,150^{\mathrm{b}}$ \\
setelah intervensi & $125,20 \pm 20,16$ & $146,00 \pm 42,87$ & $0,268^{\mathrm{b}}$ \\
$\Delta \mathbf{1}$ & $-38,3 \pm 48,98$ & $-31,30 \pm 43,02$ & $0,704^{\mathrm{a}}$ \\
$\Delta \mathbf{2}$ & $-23,50 \pm 48,01$ & $17,90 \pm 52,95$ & $0,114^{\mathrm{b}}$ \\
$\mathbf{p 1}$ & $0,035^{\mathrm{b} *}$ & $0,047^{\mathrm{a} *}$ & \\
p2 & $0,156^{\mathrm{b}}$ & $0,282^{\mathrm{b}}$ & \\
\hline$p^{*}=$ & &
\end{tabular}

Keterangan: $p^{*}=$ beda bermakna; $a=$ Wilcoxon; $b=$ paired $t$-test

$\Delta l=$ perubahan kadar trigliserida setelah pemberian jus-awal

$\Delta 2=$ perubahan kadar trigliserida setelah intervensi - setelah pemberian jus

$p=$ nilai $p$ kadar trigliserida kelompok perlakuan dan kontrol

pl= nilai $p$ kadar trigliserida awal dan setelah pemberian jus

p2= nilai $p$ kadar trigliserida setelah pemberian jus dan intervensi 


\section{PEMBAHASAN}

Variabel usia dan jenis kelamin dalam penelitian ini dilakukan matching sehingga tidak terdapat perbedaan usia antara kedua kelompok. Sebagian besar subjek dalam penelitian ini adalah perempuan. Berdasarkan status gizi dan trigliserida awal tidak terdapat perbedaan antara kelompok perlakuan dan kontrol.

Rerata asupan energi, protein, lemak, karbohidrat, kolesterol dan serat tidak terdapat perbedaan pada kelompok perlakuan dan kontrol sebelum intervensi dan selama pemberian jus lidah buaya. Rerata asupan protein, lemak dan kolesterol kedua kelompok mengalami peningkaan secara bermakna selama pemberian jus lidah buaya. Peningkatan rerata asupan lemak dan kolesterol mungkin dapat disebabkan karena siklus menu yang diberikan panti pada penelitian subjek sering mendapat makanan tinggi kolesterol seperti telur puyuh dan makanan yang diolah dengan santan, selain itu konsumsi makanan dari luar panti yang sulit dikontrol pada saat penelitian berlangsung juga dapat mempengaruhi peningkatan rerata asupan lemak dan kolesterol. Rerata asupan karbohidrat selama pemberian jus lidah buaya pada kelompok perlakuan mengalami penurunan secara bermakna, hal ini dapat dikarenakan beberapa subjek pada kelompok perlakuan kurang berselera makan sehingga memilih mengkonsumsi bubur atau mengurangi porsi nasi selama beberapa hari pada saat pemberian jus lidah buaya.

Sebelum intervensi vitamin $\mathrm{C}$ diberikan, semua subjek pada kedua kelompok diberikan jus lidah buaya untuk melihat penurunan kadar trigliserida. Kadar trigliserida kedua kelompok mengalami penurunan yang bermakna setelah pemberian jus lidah buaya dengan dosis 200 $\mathrm{mg} /$ hari selama 14 hari. Kadar trigliserida kedua kelompok pada hari ke-15 atau setelah pemberian jus lidah buaya tidak terdapat perbedaan. Penurunan ini diduga dari kandungan serat larut air yang dimiliki lidah buaya. Serat yang terkandung dalam lidah buaya merupakan serat larut air yang dipercaya dapat menurunkan risiko penyakit kardiovaskular dengan menurunkan kadar lipid di dalam plasma. Serat larut air dapat memiliki efek hipotrigliseridemia. Meskipun mekanisme hipotrigliseridemia ini belum dapat diterangkan secara jelas, tetapi serat larut air konsisten dapat menyebabkan penundaan absorbsi trigliserida dan gula dari usus halus. ${ }^{17,18}$ Serat juga memiliki efek menurunkan indeks glikemik yang juga dapat berperan dalam penurunan kadar plasma lipid. Indeks glikemik yang rendah dapat menurunkan resistensi insulin dan kadar insulin sehingga menyebabkan penurunan asam lemak bebas yang dapat mencegah akumulasi trigliserida dalam darah. ${ }^{19}$ Serat larut air yang terkandung dalam lidah buaya dapat menurunkan kadar kolesterol total, mencegah peningkatan trigliserida terutama yang disebabkan karena pola makan tinggi karbohidrat. ${ }^{20}$

Kandungan niasin atau vitamin B3 yang terdapat dalam lidah buaya diduga dapat mengurangi asam lemak bebas dengan menghambat enzim hormon sensitif lipase. Berkurangnya asam lemak bebas dalam darah membuat sintesis VLDL dalam hati menurun sehingga mengakibatkan penurunan kadar trigliserida dan kadar LDL plasma. ${ }^{12}$ Selain niasin, magnesium yang terkandung dalam lidah buaya diduga dapat menurunkan kadar trigliserida darah. Magnesium di dalam lidah buaya dapat menurunkan kadar trigliserida dengan menurunkan produksi Apolipoprotein B yang merupakan prekusor VLDL, sehingga menurunkan sintesis VLDL. Vitamin dan mineral tersebut juga memiliki efek sebagai antioksidan dan menghambat proses atherosklerosis. ${ }^{21,22}$

Rerata asupan energi, protein, lemak, karbohidrat, kolesterol, serat dan vitamin C selama intervensi tidak terdapat perbedaan antara kelompok kontrol dan perlakuan. Rerata asupan protein pada kelompok perlakuan dan kontrol mengalami penurunan secara signifikan selama intervensi. Rerata asupan lemak kelompok perlakuan mengalami peningkatan secara bermakna selama intervensi berlangsung. Selama intervensi vitamin $\mathrm{C}$ berlangsung rerata asupan karbohidrat kelompok kontrol mengalami peningkatan secara bermakna. Rerata asupan kolesterol meningkat secara bermakna pada kelompok perlakuan dan kontrol selama intervensi vitamin $\mathrm{C}$ berlangsung. Rerata asupan serat pada kedua kelompok mengalami peningkatan secara bermakna, peningkatan rerata asupan serat ini kemungkinan dapat disebabkan selama penelitian subjek selalu menghabiskan porsi sayur dan buah yang diberikan oleh pihak panti, akan tetapi peningkatan asupan serat ini belum memenuhi kecukupan asupan serat yang dianjurkan.

Pemberian vitamin C sebanyak 750 $\mathrm{mg} /$ hari selama tiga hari, setelah pemberian jus lidah buaya yang diberikan pada kelompok perlakuan menunjukkan penurunan kadar trigliserida, akan tetapi penurunan tersebut tidak bermakna. Kelompok kontrol yang diberi plasebo selama 3 hari setelah intervensi menunjukkan peningkatan kadar trigliserida, tetapi tidak bermakna. Peningkatan rerata kadar trigliserida ini 
dimungkinkan karena adanya peningkatan rerata asupan kolesterol selama intervensi berlangsung. Rerata kadar trigliserida antara kedua kelompok menunjukkan tidak terdapat perbedaan setelah intervensi vitamin $\mathrm{C}$.

Hasil penelitian ini menunjukkan adanya penurunan rerata kadar trigliserida setelah diberi vitamin C meskipun tidak signifikan. Vitamin $C$ sebagai antioksidan berfungsi menangkap radikal peroksil sehingga dapat melindungi LDL dari kerusakan oksidatif, menfasilitasi penyerapan VLDL dan meningkatkan ekskresi VLDL dari plasma. Konsentrasi vitamin $\mathrm{C}$ yang tinggi dalam darah akan menurunkan kadar LDL, trigliserida dan meningkatkan HDL darah. ${ }^{23}$ Vitamin $\mathrm{C}$ juga berperan sebagai homeostatis dengan menurunkan kadar trigliserida yang tinggi, tetapi tidak menurunkan kadar trigliserida dalam kategori normal. ${ }^{13}$ Vitamin $\mathrm{C}$ diperlukan tubuh sebagai kofaktor dalam mensintesis karnitin. Karnitin berfungsi untuk mengatur oksidasi asam lemak, defisiensi vitamin $\mathrm{C}$ akan menurunkan sintesis karnitin. Konsentrasi vitamin $\mathrm{C}$ yang tinggi dapat meningkatkan sintesis karnitin dari lisin dan metionin dalam hati. Peningkatan sintesis karnitin ini dapat meningkatkan beta oksidasi asam lemak, yang meningkatkan pembakaran asam lemak sehingga mengakibatkan penurunan kadar trigliserida dalam darah. ${ }^{24}$

Penurunan kadar trigliserida yang tidak signifikan setelah intervensi vitamin $\mathrm{C}$ kemungkinan dapat disebakan karena waktu pemberian vitamin $\mathrm{C}$ yang kurang lama. Akan tetapi, pemberian vitamin C dalam jangka waktu yang lama pada kelompok usia lanjut dikhawatirkan dapat menimbulkan efek samping seperti, diare dan ekskresi asam oksalat berlebih. ${ }^{25}$ Penelitian menyebutkan pemberian vitamin C sebanyak 500-1000 mg setiap hari selama minimal empat minggu dapat menurunkan kadar trigliserida dari $210 \pm 65,1 \mathrm{mg} / \mathrm{dl}$ menjadi $186,56 \pm 54 \mathrm{mg} / \mathrm{dl} .^{23}$

\section{SIMPULAN}

Pemberian jus lidah buaya dapat menurunkan kadar trigliserida lansia secara bermakna. Pemberian vitamin $\mathrm{C}$ dengan dosis sebesar $750 \mathrm{mg} /$ hari selama 3 hari tidak terbukti dapat mempertahankan penurunan kadar trigliserida setelah pemberian jus lidah buaya.

\section{SARAN}

Diperlukan penelitian lebih lanjut dengan pemberian vitamin $\mathrm{C}$ pada lansia dalam waktu yang lebih lama, tetapi juga tetap mempertimbangkan kemungkinan efek samping yang akan timbul.

\section{DAFTAR PUSTAKA}

1. Mayes, PA. Metabolisme Asilgliserol dan Sfingolipid. Dalam: Murray RK, Granner DK, Mayes PA, Roodwell VW, editors. Biokimia Harper. Edisi 24. Jakarta: Penerbit Buku Kedokteran EGC: 1997. hal: 251-253.

2. Brunzell, John D. Hypertiglyceridemia. N Engl J Med 2007; 357: 1009-17

3. Dinas Kesehatan Republik Indonesia. Laporan Hasil Riset Kesehatan Dasar (RISKESDAS) Nasional 2013.

4. Dinas Kesehatan Kota Semarang. Laporan Kematian Akibat Penyakit Tidak Menular 2011.

5. Roos, NM. The Potential and Limits of Functional Foods in Preventing Cardiovascular Disease. In : Arnoldi, A, editor. Functional Foods, Cardiovascular Disease and Diabetes. New YorkCRC Press; 2004.p.1

6. Syamsuhidayat SS, dan Hutapea JR. Inventaris Tanaman Obat Indonesia I. Jakarta: Departeman Kesehatan Indonesia. 1991.

7. Citra Anindya Astari, Zulkhah Noor. Pengaruh Pare dan Lidah Buaya Terhadap Kadar Trigliserida Darah sebagai Terapi Herbal DM pada Tikus Putih yang Diinduksi Aloksan. Universitas Muhammadiyah Yogyakarta. 2010.

8. Hermawan Istiadi, Endang SS. Pengaruh Jus Lidah Buaya (Aloe vera linn) terhadap Kadar Kolesterol Tikus Hiperlipidemia. Fakultas Kedokteran, Undip: Semarang; 2010.

9. Nasiff HA, Fajardo FR, Velez F et al. Efecto del Aloe Sobre la Hiperlipedemia en Pacientes Refractarios a la Dieta. Rev Cuba Med Gen Integr. 1993; 9:43-51.

10. Yongchaiyudha S, Rungipitarangsi V, Bunyapraphatsara N. Antidiabetic Activity of Aloe vera L. Juice. I. Clinical trial in new cases of diabetes mellitus. Phytomedicine. 1996; 3:241-3.

11. Yagi A, Hegazy S, Kabbash A. Possible Hypoglycemic Effect of Aloe vera L. High Molecular Weight Fractions on Type 2 Diabetic Patients. J Saudi Pharm Soc. 2009; 16:209-15.

12. Josias HH. Composition and Applications of Aloe Vera Leaf Gel. Departement of Pharmaceutical Sciences, Tshwwane University of Technology. South Africa: July 2008.

13. Sotyaningtyas, C. Vitamin C Perkuat Otot Jantung. Intisari: Jakarta. Februari 2012.

14. Maria Neresa dan Antonio Pascual. Effect of Ascorbic Acid on Dyslipidemia a study among Philippine Heart Center Employees. Philippine Heart Center: Departement of Adult Cardiology. 2010.

15. Pamuji, Slamet dan Endang SS. Pengaruh Pemberian Vitamin C terhadap Kadar Kolesterol Total Serum Tikus Wistar Jantan Hiperlipidemia 
Setelah Perlakuan Jus Lidah Buaya. Skripsi Fakultas Kedokteran, Undip: Semarang. 2005.

16. Rafighi Zahra, Arab Shahin, Mohd Yusof Rokia, Shiva Atena. The Effect of Vitamin C and E on Lipid Profile in People with Type 2 Diabetes Mellitus. Canadian Center of Science and Education. 2011.

17. Purbaya ZR. Mengenal dan Memanfaatkan Khasiat Aloe Vera (Lidah Buaya). Bandung: Pionir Jaya. 2003.

18. Radulian G, Rusu E, Dragomir A, Posea M. Metabolic effects of low glycaemic index diets. Nutrition Journal 2009, 8:5

19. Galisteo M, Duarte J, Zarzuelo A. Effects of dietary fibers on disturbances clustered in the metabolic syndrome. Journal of Nutritional Biochemistry. 2008;19;71-84

20. Nites S, William LB, Craig I Coleman. Effect of Glucomannan on Plasma Lipid and Glucose Consentrations, Body Weight, and Blood Pressure: Systematic Review and Meta-analysis. The American Journal of Clinical Nutrition. America: 2008.

21. Vinson JA, Kharra H. Al, Andreoli L. Effect of Aloe vera Preparation on the Human Bioavailability of Vitamin C and E. Departement of Chemistry, University of Scranton, USA: Desember 2003.

22. Dalimatha S. Atlas Tumbuhan Obat Indonesia Jilid 5. Jakarta: Pustaka Bunda. 2008.

23. Afkhami-Ardekani Mohammad dan ShojaoddinyArkedekani Ahmad. Effect of Vitamin C on blood Glucose, Serum Lipid dan Serum Insulin in Type 2 Diabetes Patients. Diabetes Research Center, Shahid Sadoughi University of medical Sciences and Health Services, Yazd, Iran. 2006.

24. Marc P. McRae. Vitamin C supplementation lower serum low-density lipoprotein cholesterol and triglycerides: a meta-analysis of 13 randomized controlled trials. Department of Physiology and Biochemistry, National University of Health Science. Januari:2008.

25. Combss, Gerald F. Sign and Symptomps of Vitamin Toxicities in Human in The Vitamins Fundamental Aspects in Nutrition an Health 2nd ed. California : Academic Press; 1998:540 